\title{
PENGARUH LINGKUNGAN KERJA DAN DISIPLIN KERJA TERHADAP KINERJA PEGAWAI PADA KANTOR DINAS PERINDUSTRIAN DAN PERDAGANGAN KABUPATEN LABUHANBATU UTARA
}

\author{
Ismi Hardiyanti ${ }^{1}$, Hayanuddin Safri ${ }^{2}$ \\ Dosen Tetap Sekolah Tinggi Ilmu Ekonomi (STIE) Labuhanbatu
}

\begin{abstract}
ABSTRAK
Penelitian ini bertujuan untuk mengetahui pengaruh lingkungan kerja terhadap kinerja pegawai pada Kantor Dinas Perindutrian dan Perdagangan Kabupaten Labuhanbatu Utara. Untuk mengetahui pengaruh disiplin kerja terhadap kinerja pegawai pada Kantor Dinas Perindutrian dan Perdagangan Kabupaten Labuhanbatu Utara. Untuk mengetahui pengaruh lingkungan kerja dan disiplin kerja berpengaruh terhadap kinerja pegawai pada Kantor Dinas Perindutrian dan Perdagangan Kabupaten Labuhanbatu Utara. Jenis penelitian ini adalah penelitian asosiatif. Pengumpulan data dalam penelitian ini dilakukan melalui pendekatan survey dengan jenis penelitian deskriptif kuantitatif dengan menyebar kuesioner kepada 35 responden sedangkan populasi yang dijadikan dalam penelitian ini pegawai Kantor Dinas Perindustrian Dan Perdagangan Kabupaten Labuhanbatu Utara. Teknik pengumpulan data dilakukan dengan wawancara, kuesioner dan studi dokumentasi. Teknik analisis data yang digunakan dalam penelitian ini adalah analisis deskriptif, analisis regresi linear berganda, pengujian hipotesis dengan menggunakan uji signifikan simultan (uji F), pengujian signifikan parsial (uji t), dan pengujian koefisien determinasi $\left(\mathrm{R}^{2}\right.$ ). Hasil penelitian ini menunjukkkan bahwa secara parsial bahwa variabel lingkungan kerja tidak berpengaruh positif dan signifikan terhadap kinerja pegawai, secara parsial bahwa variabel disiplin kerja berpengaruh positif dan signifikan terhadap kinerja pegawai dan secara serempak bahwa variabel lingkungan kerja dan disiplin kerja berpengaruh positif dan signifikan terhadap kinerja pegawai.
\end{abstract}

\section{Kata Kunci: Lingkungan Kerja, Disiplin Kerja, Kinerja Pegawai.}

\section{PENDAHULUAN}

Kinerja pegawai dalam organisasi yang kondusif tidak terlepas dari lingkungan kerja yang baik dan selalu merasa nyaman diantara pegawainya dan kinerja pegawai dalam organisasi dapat terwujud sesuai dengan visi misi organisasi dipengaruhi kuat oleh disiplin kerja yang ditunjukkan pegawai setiap kali melakukan aktivitas kerjanya.

Lingkungan kerja menjadi faktor utama dalam organisasi untuk diperhatikan manajemen. Meskipun lingkungan kerja tidak melaksanakan proses produksi dalam suatu organisasi, namun lingkungan kerja mempunyai pengaruh langsung terhadap para pegawai yang melaksanakan proses produktivitas tersebut. Lingkungan kerja yang baik akan memuaskan pegawai, karena dapat meningkatkan kinerja, sebaliknya lingkungan kerja yang tidak memadai akan dapat menurunkan kinerja dan akhirnya menurunkan motivasi kerja pegawai. 
Kondisi lingkungan kerja dikatakan baik atau sesuai apabila manusia dapat melaksanakan kegiatan secara optimal, sehat, aman dan nyaman. Kesesuaian lingkungan kerja dapat dilihat akibatnya dalam jangka waktu yang lama. Lebih jauh lagi lingkungan kerja yang kurang baik dapat menuntut tenaga kerja dan waktu yang lebih banyak dan tidak mendukung diperolehnya dari rancangan sistem kerja yang efisien. Faktor tersebut merupakan satu-kesatuan untuk diterapkan secara disiplin dalam menjalankan tugasnya.

Kenyamanan tempat kerja secara fisik dan non fisik merupakan harapan bagi tiap pegawai dalam menjalankan tugas untuk mencapai suatu tujuan yang telah ditetapkan seperti ruangan yang nyaman, penerangan, warna dinding dan perabotan kantor serta kebersihan ruangan kerja pegawai yang selalu terjaga. Pada akhirnya kondisi kerja akan lebih baik dan mengurangi kejenuhan dan kelelahan, pegawai akan bekerja secara optimal apabila kondisi lingkungan tempat bekerja sesuai dengan kondisi pekerjaan yang dilaksanakan

Setelah memperhatikan faktor utama, faktor lain yang dapat menyebabkan kinerja berhasil diakibatkan dari disiplin kerja. Disiplin kerja adalah suatu sikap, perilaku yang dilakukan secara sukarela dan penuh kesadaran serta keadaan untuk mengikuti peraturan yang telah ditetapkan organisasi baik tertulis maupun tidak tertulis. Perilaku tidak disiplin yang timbul merupakan cerminan dari persepsi negatif pegawai terhadap kontrol yang dilakukan oleh perilaku pimpinan. Sebaliknya perilaku disiplin seorang pimpinan yang timbul merupakan cerminan dari persepsi positif terhadap kontrol atasan atau pimpinan.

Berkaitan dengan disiplin untuk memelihara dan meningkatkan kedisiplinan yang baik adalah hal yang sulit, karena banyak faktor yang empengaruhinya. Faktor-faktor tersebut antara lain tujuan dan kemampuannya, teladan pimpinan, balas jasa (gaji dan kesejahteraan), keadilan, pengawasan melekat, sanksi hukum, ketegasan (peraturan), dan hubungan kemanusiaan. Untuk mengantisipasi situasi yang demikian, pimpinan organisasi harus selalu berusaha untuk meningkatkan kualitas dan kuantitas sumber daya manusia agar organisasi yang dipimpinnya mampu mengantarkan organisasi untuk mencapai tujuan yang diharapkan sebelumnya.

Setiap pembicaraan tentang kinerja organisasi tentu tidak akan terlepas dari lingkungan kerja dan disiplin kerja.

Mengingat bahwa lingkungan kerja dan disiplin kerja terhadap kinerja pegawai dalam suatu instansi atau organisasi itu penting, maka penulis tertarik untuk meneliti hal tersebut dalam sebuah skripsi dengan judul : Pengaruh Lingkungan Kerja Dan Disiplin Kerja Terhadap Kinerja Pegawai Pada Kantor Dinas Perindutrian Dan Perdagangan Kababupaten Labuhanbatu Utara.

\section{Perumusan Masalah}

Adapun permasalahan dalam penelitian ini adalah :

1. Bagaimana lingkungan kerja berpengaruh terhadap kinerja pegawai pada Kantor Dinas Perindutrian dan Perdagangan Kabupaten Labuhanbatu Utara? 
2. Bagaimana disiplin kerja berpengaruh terhadap kinerja pegawai pada Kinerja PegawaipadaKantor Dinas Perindutrian dan Perdagangan Kabupaten Labuhanbatu Utara?

3. Bagaimana lingkungan kerja dan disiplin kerja berpengaruh terhadap kinerja pegawai pada Kantor Dinas Perindutrian dan Perdagangan Kabupaten Labuhanbatu Utara ?.

\section{TINJAUAN PUSTAKA}

\section{Lingkungan Kerja}

Menurut Robbins (2001), sebuah lingkungan dalam organisasi terdiri dari lembaga-lembaga atau kekuatan dari luar organisasi dan berpotensi mempengaruhi kinerja organisasi. Sedangkan pengertian lingkungan kerja menurut Alex S. Nitisemito (2000) adalah segala sesuatu yang ada disekitar para pekerja yang dapat mempengaruhi dirinya dalam menjalankan tugas-tugasnya. Menurut Sedarmayati (2001), lingkungan kerja adalah keseluruhan alat perkakas dan bahan yang dihadapi, lingkungan sekitarnya di mana seseorang bekerja, metode kerjanya, serta pengaturan kerjanya baik sebagai perseorangan maupun sebagai kelompok. Lingkungan kerja adalah keseluruhan atau setiap aspek dari gejala fisik dansosial-kultural yang mengelilingi atau mempengaruhi individu. (Komarudin, 2002 : 142). Lingkungan kerja fisik adalah segala sesuatu yang ada di sekitar para pekerja yang dapat mempengaruhi dirinya dalam menjalankan tugas-tugas yang dibebankan, misalnya penerangan, suhu udara, ruang gerak, keamanan, kebersihan, musik dan lain-lain (Alex. S. Nitisemito, 2002 : 183).

Berdasarkan definisi tersebut dapat dinyatakan lingkungan kerja fisik adalah segala sesuatu yang ada di sekitar karyawan bekerja yang mempengaruhi karyawan dalam melaksanakan beban tugasnya. Masalah lingkungan kerja dalam suatu organisasi sangatlah penting, dalam hal ini diperlukan adanya pengaturan maupun penataan faktor- faktor lingkungan kerja fisik dalam penyelenggaraan aktivitas organisasi. Lingkungan kerja fisik adalah segala sesuatu yang ada di sekitar para pekerja yang dapat mempengaruhi dirinya didalam melaksanakan tugas-tugasnya. Dapat disimpulkan bahwa variabel lingkungan kerja merupakan segala sesuatu yang berbentuk fisik maupun non fisik dari lingkungan tempat kita bekerja, dimana lingkungan kerja fisik meliputi lingkungan kerja yang langsung berhubungan dengan karyawan seperti fasilitas dan sarana kerja, dan kategori kedua, lingkungan kerja umum yang mempengaruhi kondisi manusia seperti suhu, kelembaban, pencahayaan, kebisingan dan sirkulasi udara. Untuk lingkungan kerja non fisik meliputi hubungan kerja karyawan dengan rekan kerja, atasan maupun bawahan.

Sedarmayanti (2001) menyatakan bahwa secara garis besar, jenis lingkungan kerja terbagi menjadi 2 yakni :

\section{Lingkungan Kerja Fisik}

Lingkungan kerja fisik adalah semua keadaan berbentuk fisik yang terdapat di sekitar tempat kerja yang dapat mempengaruhi karyawan baik secara langsung maupun tidak langsung (Sedarmayanti, 
2001). Lingkungan kerja fisik dapat dibagi dalam dua kategori, pencahayaan, kebisingan, getaran mekanis, bau tidak sedap, warna, dan lain-lain.

\section{Lingkungan Kerja Non Fisik Lingkungan kerja non fisik}

adalah semua keadaan yang terjadi yang berkaitan dengan hubungan kerja, baik hubungan dengan atasan maupun hubungan sesama rekan kerja, ataupun hubungan dengan bawahan (Sedarmayanti, 2001). Dalam suatu organisasi atau perusahaan, karyawan akan terlibat dalam hubungan kerja antara karyawan dengan karyawan, karyawan dengan atasan, dan kedua-duanya sama-sama memberikan pengaruh terhadap kinerja karyawan.

Terdapat bermacam-macam faktor yang mempengaruhi lingkungan kerja dimana kegiatan dilaksanakan, yaitu :

- Perlengkapan dan fasilitas

- Suasana kerja (non physical workingenvironment)

- Lingkungan tempat kerja (physicalworking environment) (Sarwoto, 1981: 131)

Dalam bukunya Anoraga (1990 : 44), dikemukakan bahwa lingkungan kerja yang baik perlu memperhatikan hal-hal sebagai berikut: musik, pertukaran udara, penerangan yang cukup, kebisingan.

Dari uraian diatas maka peneliti mengambil kesimpulan bahwa faktor-faktor yang mempengaruhi lingkungan kerja adalah Perlengakapan dan fasilitas, suasana kerja (lingkungan non fisik), lingkungan tempat kerja (lingkungan fisik). Penjelasan dari masing-masing faktor dapat dilihat dalam uraian berikut ini :1. Perlengkapan dan fasilitas

Fasilitas adalah segala sesuatu yang ditempati dan dinikmati oleh pegawai baik dalam hubungan langsung maupun tidak langsung. Dari pengertian di atas yang dimaksud fasilitas di atas adalah :

a. Fasilitas alat kerja yaitu semua benda yang berfungsi langsung digunakan dalam melaksanakan pekerjaannya.

b. Fasilitas perlengkapan yaitu merupakan semua benda atau barang yang digunakan dalam pekerjaan, tetapi tidak langsung digunakan untuk menyelesaikan pekerjaan melainkan berfungsi sebagai pelancar dalam pekerjaan.

c. Fasilitas sosial yaitu merupakan suatu fasilitas yang digunakan oleh pegawai dan berfungsi sosial, misalnya dapat berupa penyediaan mess, asrama untuk pegawai yang belum menikah.

Suasana kerja (lingkungan non fisik)

Terdapat ungkapan atau pernyataan bahwa organisasi adalah kumpulan orang-orang, hal ini adalah suatu ungkapan yang biasa namun meskipun demikian hal ini menitik beratkan pada pentingnya orang-orang dalam pekerjaan pengorganisasian. Hal inilah yang menimbulkan ide pokok bahwa 
orang-orang membentuk pusat dimana keluar konsep-konsep organisasi tentang pekerjaan yang harus dilakukan, otoritas dan lingkungan kerja.

Dengan adanya suatu lingkungan kerja yang baik dan menyenangkan maka pegawai akan bersemangat dalam melaksanakan pekerjaannya. Suasana kerja dapat mendukung tumbuhnya semangat kerja pegawai dan sangat mempengaruhi pula bagi tercapainya tujuan organisasi. Suasana kerja yang baik dapat tercipta dengan adanya penyusunan organisasi, karena ini

merupakan suatu alat yang memberikan pengelompokan kegiatan-kegiatan khusus dan mengelompokkan orang-orang dan menerapkan tujuan manajemen. Dengan penyusunan oraganisasi yang baik dan pembagian tugas yang jelas dapat menciptakan suasana kerja yang sehat sehingga dapat menumbuhkan semangat kerja pegawai.

Nawawi dan Martini (2001 : 129) mengemukakan bahwa faktor non fisik dalam lingkungan kerja adalah penghargaan, penghormatan, pengakuan dan perlakuan yang wajar serta bersifat manusiawi, toleransi, solidaritas, dan tanggung jawab.

Dari beberapa pokok-pokok di atas dapat dijelaskan bahwa, pegawai juga memerlukan adanya suatu penghargaan yang sifatnya nonfinansial baik dari pimpinan maupun dari rekan kerja, seperti pujian, pengakuan atas prestasi yang dicapainya, hal ini akan mendorong pegawai untuk lebih giat dalam melaksanakan pekerjaan. Selain itu perlakuan yang wajar tanpa adanya tekanantekanan atau diskriminasi sangat dibutuhkan bagi para pegawai. Dengan demikian akan tercipta suatu suasana kerja yang menyenangkan. Struktur organisasi yang tepat, terdapat kerjasama antar pegawai tanpa adanya diskriminasi, hal ini akan mempengaruhi pegawai untuk lebih bertanggung jawab dalam melaksanakan tugas mereka.

3. Lingkungan tempat kerja (lingkungan fisik)

\section{a. Pewarnaan}

Masalah pewarnaan ini bukan hanya pewarnaan dinding saja, tetapi sangat luas, sehingga dapat juga pewarnaan mesin-mesin, peralatan, bahkan pewarnaan dari seragam yang mereka pakai perlu mendapat perhatian. Dengan memakai warna yang tepat pada

dinding ruangan dan alat-alat lainnya, kegembiraan dan ketenangan bekerja para pegawai akan terpelihara. Selain itu warna yang tepat akan mencegah kesilauan yang mungkin timbul karena cahaya yan berlebihan (Liang Gie, 2004 : 216).

Komposisi warna yang salah dapat pula mengganggu pemandangan. Sehingga dapat menimbulkan rasa tidak atau kurang menyenangkan bagi mereka yang memandang. Dan rasa tidak menyenangkan ini dapat mempengaruhi semangat dan kegairahan kerja para pegawai (Nitisemito, 2006 : 185). Pemilihan warna yangsesuai bukan hanya pada warna dinding saja, tetapi juga termasuk pewarnaan perabot, peralatan maupun perlengkapan, bahkan warna seragam yang dipakai pegawai juga harus 
diperhatikan. Dengan demikian akan timbul keseragaman komposisi warna yang enak dipandang mata.

Penggunaanwarna yang baik akan memberikan keuntungan sebagai berikut :

- Memungkinkan kantor menjadi tempat yang menyenangkan dan menarik

- Mempunyai akibat yang tidak langsung terhadap produktivitas pegawai .

\section{b. Kebersihan}

Kebersihan merupakan syarat pertama untuk pegawai-pegawai yang sehat dan pelaksanaannya tidak akan memerlukan banyak ongkos. Dalam setiap urusan hendaknya selalu menjaga kebersihan lingkungan, sebab selain mempengaruhi kesehatan juga akan mempengaruhi kesehatan jiwa seseorang. Lingkungan kerja yang bersih bisa menimbulkan rasa senang, dan rasa senang ini akan dapat mempengaruhi

seseorang untuk bekerja lebih bersemangat dan lebih bergairah lagi.

Kebersihan kantor mencakup kebersihan bangunan, perlengkapan dan perabotan. Karena menurut Liang Gie (2004 : 363) istilah perabot berupa meja, kursi, lemari merupakan bagian dari perlengkapan, maka uraian mengenai perabot dimasukkan ke dalam kebersihan perlengkapan.

\section{1) Kebersihan Bangunan}

Semua bagian dari bangunan gedung hendaknya selalu bersih, seperti dinding, lantai, langit-langit, halaman sekitar gedung dan bagian gedung yang lain (kamar mandi dan WC). Dinding, lantai hendaknya bebas dari corat-coret atau noda-noda lain, seperti bekas telapak kaki. Demikian juga tidak ada sarang laba-laba yang bergelantungan. Untuk menjaga agar lantai tetap bersih hendaknya lantai selalu disapu dan dipel. Selain itu hendaknya disediakan keset disetiap pintu masuk dan keranjang sampah disetiap ruangan. Kamar mandi dan WC sebagai bagian yang diperlukan bagi para pegawai hendaknya selalu terjaga kebersihannya. Untk menghindari bau yang tidak enak di kamar mandi/WC bisa dengan memberi bahan kimia seperti karbol misalnya. Hal yang lebih penting lagi adalah air, air harus selalu tersedia dan bersih adanya. Tidak ketinggalan pula perlengkapan kamar mandi seperti gayung, sabun mandi, lap/handuk hendaknya tersedia, karena tanpa itu kamar mandi/WC kurang berfungsi sebagaimana mestinya.

2) Kebersihan Perlengkapan Perlengkapan kantor seperti meja, kursi, lemari, mesin kantor harus selalu bersih. Jika para karyawan akan bekerja tidak perlu lagi disibukkan dengan perlengkapan kantor yang masih kotor. Oleh karena itu setiap mulai jam kerja hendaknya semua perabot yang diperlukan sudah dalam keadaan bersih.

Mesin-mesin juga secara rutin selalu dibersihkan sehingga tidak macet jika sedang digunakan, karena kotoran-kotoran yang menumpuk di dalam mesin akan mengganggu bekerjanya mesin-mesin tersebut. 
Dalam usaha menciptakan lingkungan kerja yang bersih, pimpinan harus dapat menanamkan pentingnya kebersihan bagi para pegawai. Mengingat para pegawai mempunyai tugas tersendiri, maka disina sangat diperlukan petugas kebersihan untk menjaga kebrsihan lingkungan.

c. Penerangan

Penerangan di dalam lingkungan kerja maksudnya adalah cukupnya sinar yang masuk ke dalam ruang kerja masing-masing pegawai kantor. Dengan tingkat penerangan yang cukup di dalam ruang kerja, akan mendorong pegawai untk bekerja lebih baik. Dengan demikian pelaksanaan dan hasil kerja yang diperoleh pegawai akan menjadi lebih baik. Penerangan yang tidak memadai akan mengakibatkan para pegawai tidak jelas melihat dan mengamati pekerjaan yang dilaksanakannya. Dalam hal ini akan memperbesar tingkat kesalahan para pegawai tersebut.

\section{Disiplin Kerja}

Sikap disiplin kerja karyawan sangat penting bagi suatu perusahaan dalam rangka mewujudkan suatu tujuan perusahaan, hal ini sesuai dengan

penjelasan Malayu S.P Hasibuan (2001:213) bahwa "Disiplin harus ditegakkan dalam suatu organisasi perusahaan, karena tanpa dukungan disiplin karyawan yang baik sulit bagi perusahaan untuk mewujudkan tujuannya". Dengan adanya disiplin kerja pada setiap karyawan yang ada di dalam perusahaan tersebut, akan menjadikan perusahaan itu menjadi maju. karena

setiap karyawan yang berdisiplin dalam melakukan pekerjaan dapat menyelesaikan tugas-tugas yang ada di dalam perusahaan tersebut walaupun tidak secara keseluruhan menghasilkan pekerjaan yang sempurna. Tetapi dalam jangka waktu tertentu karyawan akan melaksanakan pekerjaannya menjadi lebih baik.

Satrohadiwiryo (2002:291) menjelaskan arti Disiplin sebagai

berikut:"Suatu sikap menghormati, menghargai patuh dan taat terhadap peraturan-peraturan yang berlaku, baik yang tertulis maupun tidak, serta sanggup menjalankannya, serta tidak mengelak untuk menerima sanksi-sanksi apabila ia melanggar tugas dan wewenag yang diberikan kepadanya. Disiplin kerja menurut Rivai (2005:444) adalah Suatu alat yang digunakan para manajer untuk berkomunikasi dengan karyawan agar mereka bersedia mengubah suatu perilaku serta sebagai suatu upaya untuk meningkatkan kesadaran dan kesediaan seseorang mentaati semua peraturan perusahaan dan normanorma sosial yang berlaku.

Sinungan (2000:146) menjelaskan bahwa disiplin kerja itu "Sikap mental yang tercermin dalam perbuatan atau tingkah laku perorangan, kelompok atau masyarakat berupa kepatuhan atau ketaatan terhadap peraturan-peraturan yang di tetapkan baik oleh pemerintah etik, norma, dan kaidah yang berlaku dalam masyarakat untuk tujuan tertentu". Selanjutnya Keith Davis (1985:366) yang di kutip oleh Anwar Prabu Mangkunegara (2001:129) "Dicipline is managementaction to enforce organization standar" ( 
Disiplin kerja diartikan sebagai pelaksanaanmanajemen untuk memperteguh pedoman-pedoman organisasi.Berdasarkan pengertian-pengertian diatas dapat disimpulkan bahwa yang dimaksud dengan disiplin kerja adalah sikap mental yang tercermin dalam perbuatan perorangan maupun kelompok berupa kepatuhan atau ketaatan terhadap peraturan-peraturan yang di tetapkan untuk memperteguh pedoman-pedoman organisasi.

\section{Jenis - jenis disiplin kerja}

Disiplin yang mantap pada hakekatnya akan tumbuh dan terpancar dari hasil kesadaran manusia. Disiplin yang tidak bersumber dari hati nurani manusia akan menghasilkan disiplin yang lemah dan tidak bertahan lama. Disiplin akan tumbuh dan dapat dibina melalui latihan, pendidikan atau penanaman

kebiasaan dengan keteladanan-keteladanan tertentu, yang harus dimulai sejak ada dalam lingkungan keluarga, mulai pada masa kanak-kanak dan terus tumbuh berkembang dan menjadikannya bentuk disiplin yang semakin kuat

Disiplin harus selalu dipupuk dan dibina agar tumbuh dan berkembang menjadi sikap disiplin dalam setiap pelaksanaan tugas. Dalam hal ini disiplin kerja dapat dibedakan menjadi 3 yaitu :

\section{Disiplin Preventif}

Merupakan kegiatan yang dilakukan dengan maksud untuk mendorong para anggota agar secara sadar mentaati berbagai standart dan aturan, sehingga dapat dicegah berbagai penyelewengan atau pelanggaran Lebih utama dalam hal ini adalah dapat ditumbuhkan "Self Dicipline" pada setiap anggota tanpa kecuali. Manajemen kesatuan Polri mempunyai tanggung jawab untuk menciptakan suatu iklim disiplin preventif dimana berbagai standar diketahui dan dipahami. Untuk memungkinkan iklim yang penuh disiplin kerja tanpa paksaan tersebut perlu kiranya standart itu sendiri bagi setiap anggota, dengan demikian dapat dicegah kemungkinan-kemungkinan timbulnya

pelanggaran-pelanggaran atau penyimpangan dari standart yang ditentukan.

\section{Disiplin Korektif}

Disiplin ini merupakan kegiatan yang diambil untuk menangani pelanggaran yang telah terjadi terhadap aturan-aturan dan mencoba untuk menghindari pelanggaran lebih lanjut. Kegiatan korektif ini dapat berupa suatu bentuk hukuman dan disebut tindakan pendisiplinan (disciplinary action).

\section{Disiplin Progresif}

Disiplin ini berarti memberikan hukuman-hukuman yang lebih berat terhadap pelanggaranpelanggaran yang berulang. Tujuannya adalah memberikan kesempatan kepada anggota untuk mengambil tindakan korektif sebelum hukuman-hukuman yang lebih serius dilaksanakan. Disiplin progresif juga Memungkinkan manajemen untuk membantu anggota memperbaiki kesalahan. 
Dalam organisasi Polri yang diinginkan adalah jenis disiplin preventif yang timbul dari diri sendiri atas dasar kerelaan dan kesadaran. Akan tetapi dalam kenyataan selalu mengatakan bahwa disiplin itu lebih banyak disebabkan adanya paksaan dari luar dan hak-hak anggota sudah menjadi alat pengenalan yang tepat kepada disiplin anggota, karena hak-hak anggota seringkali merupakan masalah dalam kasus-kasus disiplin anggota. Demikian juga dalam penelitian ini jenis-jenis disiplin kerja yang dikaji adalah disiplin preventif yang dilaksanakan untuk mendorong anggota agar mengikuti aturan yang telah ditetapkan.

\section{Kinerja}

Kinerja adalah hasil kerja yang dapat dicapai oleh seseorang atau sekelompok orang dalam satu organisasi, sesuai dengan wewenang dan tanggung jawab masing-masing, dalam rangka mencapai tujuan organisasi bersangkutan secara legal, tidak melanggar hukum dan sesuai dengan moral dan etika. (Suyadi, 1999:20). Menurut Soeprihanto (2000:27), penilaian kinerja adalah suatu sistem yang digunakan untuk menilai dan mengetahui apakah seseorang pegawai telah melaksanakan pekerjaannya masing-masing secara keseluruhan. Seperti yang telah melaksanakan pekerjaannya masing-masing secara keseluruhan. Seperti yang telah dikemukakan bahwa pelaksanaan pekerjaan secara keseluruhan bukan bararti hanya dilihat atau dinilai hasil fisiknya tetapi meliputi berbagai hal, seperti kemampuan kerja, disiplin hubungan kerja, prakarsa, kepemimipinan dan hal-hal khusus sesuai dengan bidang level pekerjaan yang dijabatnya.

Menurut Soeprihanto (2000:80), tujuan penilaian kinerja adalah sebagai berikut :

- Mengetahui keadaan keterampilan dan kemampuan para karayawan secara rutin.

- Untuk dujadikan sebagai dasar perencanaan di bidang personalia, khususnya penyempurnaan kondisi kerja, peningkatan mutu dan hasil kerja.

- Dapat dipakai sebagai dasar pengembangan dan pendayagunaan karyawan seoptimal mungkin, sahingga antara lain dapat diarahkan jenjang karier.

- mendorong timbulnya hubungan timbale balik antara atasan dan bawahan mengetahui kondisi perusahaan secara keseluruhan dari bidang personalia, khususnya kinerja karyawan dalam bekerja.

Secara pribadi karyawan dapat mengetahui kekuatann dan kelemahan masing-masing, sehingga dapat memacu perkembangannya. Sebaliknya bagi atasan yang menilai akan lebih memperhatikan dan mengenal bawahannya, sehingga dapat membantu dalam memotivasi karyawan dalam bekerja. Hasil penelitian kinerja dapat bermanfaat bagi penelitian dan pengembangan dibidang personalia secara keseluruhan

\section{Hipotesis Penelitian}


Hipotesis adalah suatu perumusan sementara mengenai suatu hal yang dibuat untuk menjelaskan hal itu dan juga dapat menuntun/ mengarahkan penyelidikan selanjutnya. Hipotesis yang penulis kemukakan dalan penelitian ini, diduga bahwa:

Lingkungan kerja berpengaruh Positif dan Signifikan terhadap kinerja pegawai pada Kantor Dinas Perindutrian dan Perdagangan Kabupaten Labuhanbatu Utara

Disiplin kerja berpengaruh Positif dan Signifikan terhadap kinerja pegawai pada Kantor Dinas Perindutrian dan Perdagangan Kabupaten Labuhanbatu Utara

Lingkungan kerja dan disiplin kerja berpengaruh Positif dan Signifikan terhadap kinerja pegawai pada Kantor Dinas Perindutrian dan Perdagangan Kabupaten Labuhanbatu Utara.

\section{METODE PENELITIAN}

\section{Populasi}

Populasi adalah keseluruhan dari sekumpulan elemen atau objek dan subjek yang memiliki sejumlah karakteristik umum yang diminati oleh peneliti untuk dipelajari, diteliti dan kemudian ditarik kesimpulan (Sugiyono, 2006). Dalampenelitian ini yang menjadi populasi adalah seluruh pegawai Kantor Dinas Perindustrian Dan Perdagangan Kabupaten Labuhanbatu Utara sebanyak

35 orang. Oleh karena itu sampel dalam penelitian ini adalah keseluruhan pegawai Kantor Camat Kualuh Selatan Kabupaten Labuhanbatu Utara berjumlah 35 orang. Adapun metode sampling jenuh,yaituteknik penentuan sampel apabila semua populasi digunakan sebagai sampel.

\section{Metode Analisis Data}

Adapun bentuk persamaan regresi linear berganda yang digunakan dapat dirumuskan:

$$
\mathbf{Y}=+\mathbf{X}_{1}+\mathbf{X}_{2}+\mathbf{e}
$$

Keterangan :

Y : Kinerja

: Koefisien Konstanta.

$1, \quad 2 \quad: \quad$ Koefisien Variabel Bebas

$\mathrm{X}_{1} \quad$ : $\quad$ Lingkungan kerja

$\mathrm{X}_{2} \quad$ : Disiplin kerja

e : Faktor Pengganggu

Dalam analisis regresi berganda ada tiga jenis kriteria ketepatan, yaitu:

Uji Simultan ( Fhitung) 
Uji simultan bertujuan untuk mengetahui pengaruh bersama-sama variabel independen terhadap variabel dependen.

Kriteria pengujiannya sebagai berikut: $\mathrm{H}_{\mathrm{o}}: \mathrm{b}_{1}=\mathrm{b}_{2}=0$, artinya variabel independen secara bersamasama tidak berpengaruh terhadap variabel dependen.

$\mathrm{H}_{\mathrm{i}}: \mathrm{b}_{1} \neq \mathrm{b}_{2}=0$, artinya variabel independen secara bersama-sama berpengaruh terhadap variabel dependen.

Dengan kriteria pengambilan keputusan:

Jika nilai Fhitung > nilai Ftabel, maka $\mathrm{H}_{0}$ ditolak dan $\mathrm{H}_{\mathrm{a}}$ diterima $\alpha=5 \%$

Jika nilai Fhitung $<$ nilai Ftabel, maka $\mathrm{H}_{0}$ diterima dan $\mathrm{H}_{\mathrm{a}}$ ditolak $\alpha=5 \%$.

\section{Uji Parsial (Uji t)}

Uji parsial (thitung) bertujuan untuk

mengetahui besarnya pengaruh masing-masing variabel independen secara individual (parsial) terhadap variabel dependen.

Kriteria pengujiannya sebagai berikut:

$\mathrm{H}_{\mathrm{o}}: \mathrm{b}_{1}=0$, artinya variabel independen secara parsial tidak

berpengaruh terhadap variabel dependen.

$\mathrm{H}_{\mathrm{i}}: \mathrm{b}_{1} \neq 0$, artinya variabel independen secara parsial berpengaruh terhadap variabel dependen.

Dengan kriteria pengambilan keputusan:

Apabila nilai thitung $>$ ttabel, maka $\mathrm{H}_{0}$ ditolak dan $\mathrm{H}_{a}$ diterima, $\alpha=5 \%$ Apabila nilai thitung $<$ tabel, maka $\mathrm{H}_{0}$ diterima dan $\mathrm{H}_{\mathrm{a}}$ ditolak $\alpha=5 \%$.

Koefisien Determinan $\left(\mathrm{R}^{2}\right)$

Koefisien determinan $\left(\mathrm{R}^{2}\right)$ digunakan untuk mengetahui seberapa baik sampel menggunakan data. $\mathrm{R}^{2}$ mengukur besarnya jumlah reduksi dalam variabel dependen yang diperoleh dari penggunaan variabel bebas. $\mathrm{R}^{2}$ mempunyai nilai antara 0 sampai 1 , dengan nilai $\mathrm{R}^{2}$ yang tinggi berkisar antar 0,7 sampai $1 . \mathrm{R}^{2}$ yang digunakan adalah nilai adjusted $\mathrm{R}^{2}$ yang merupakan $\mathrm{R}^{2}$ yang telah disesuaikan. Adjusted $\mathrm{R}^{2}$ merupakan indikator untuk mengetahui pengaruh penambahan suatu variabel independen ke dalam persamaan. 


\section{HASIL DAN PEMBAHASAN}

\section{Hasil Persamaan Regresi Linier Berganda}

Analisis regresi linear berganda bertujuan untuk mengetahui pengaruh

dari variabel-variabel independen terhadap variabel dependen, dapat dilihat pada Tabel 1 berikut ini

\section{Tabel 1}

Hasil Analisis Regresi Linier Berganda

Coefficients $^{\mathbf{a}}$

\begin{tabular}{|c|c|c|c|c|c|}
\hline \multirow[t]{2}{*}{ Model } & \multicolumn{2}{|c|}{$\begin{array}{l}\text { Unstandardized } \\
\text { Coefficients }\end{array}$} & $\begin{array}{l}\text { Standardized } \\
\text { Coefficients }\end{array}$ & & \multirow[b]{2}{*}{ Sig. } \\
\hline & $B$ & $\begin{array}{l}\text { Std. } \\
\text { Error }\end{array}$ & Beta & & \\
\hline (Constant) & -1.055 & 1.396 & & -.756 & .455 \\
\hline $\mathrm{X} 1$ & 106 & & .085 & 672 & .507 \\
\hline $\mathrm{X} 2$ & 1.169 & 168 & .884 & 6.970 & .000 \\
\hline
\end{tabular}

a. Dependent Variable: Y

\section{Sumber : Data Diolah (2014)}

Tabel 1 menunjukan bahwa model yang digunakan untuk menduga pengaruh tersebut adalah :

$Y=-1,055+0,106 X_{1}+1,169 X_{2}+e$

\section{Keterangan :}

Koefisien regresi konstanta sebesar - 1,055 mempunyai arti jika ada atau variabel lingkungan kerja dan disiplin kerja, maka kinerja pegawai akan sebesar -1,055.

Koefisien regresi lingkungan kerja sebesar 0,106 mempunyai arti bahwa setiap terjadi penambahan lingkungan kerja sebesar 0,106 maka kinerja pegawai sebesar 1 kali.

Koefisien regresi disiplin kerja sebesar 1,169 mempunyai arti bahwa setiap terjadi penambahan disiplin kerja sebesar 1,169 maka kinerja pegawai sebesar 1 kali.

\section{Analisis Koefisien Determinasi $\left(\mathbf{R}^{2}\right)$}

Analisis koefisien determinan digunakan untuk melihat seberapa besar pengaruh variabel bebas terhadap variabel terikat. Hasil pengujian koefisien determinasi dapat dilihat dari Tabel 2 sebagai berikut : 
Tabel 2

Hasil Koefisien Determinasi $\left(\mathbf{R}^{2}\right)$

Model Summary ${ }^{\text {b }}$

\begin{tabular}{|l|l|l|l|l|}
\hline Model & & & & $\begin{array}{l}\text { Std. } \\
\text { Error of } \\
\text { the } \\
\text { Estimate }\end{array}$ \\
\hline dimension 1 & $\mathbf{R}$ & Square & $\begin{array}{l}\text { Adjusted } \\
\text { R Square }\end{array}$ \\
\hline
\end{tabular}

a. Predictors: (Constant), X2, X1

b. Dependent Variable: Y

Sumber : Data Diolah (2014)

Pada bagian ini ditampilkan nilai $\mathrm{R}, \mathrm{R}^{2}$, adjusted $R^{2}$, dan standard error.

Nilai R sebesar 0,963 sama dengan 96,3\% yang menunjukan bahwa hubungan antara variabel lingkungan kerja dan disiplin kerja terhadap kinerja pegawai cukup erat.

Besarnya nilai koefisien determinasi 0,928 atau sama dengan 92,8\%. Nilai tersebut berarti bahwa sebesar 92,8\% menegaskan bahwa kinerja pegawai dapat dijelaskan melalui variabel lingkungan kerja dan disiplin kerja.

\section{Pengujian Hipotesis}

\section{Hasil Uji Serempak (Uji F)}

Uji F ini dilakukan untuk menguji secara serempak apakah disiplin kerja dan sanksi berpengaruh terhadap motivasikerja, dapat dilihat pada Tabel 3 berikut :

Tabel 3

Hasil Uji Serempak (Uji F)

ANOVA $^{b}$

\begin{tabular}{|l|l|l|l|l|l|}
\hline Model & $\begin{array}{l}\text { Sum of } \\
\text { Squares }\end{array}$ & df & $\begin{array}{l}\text { Mean } \\
\text { Square }\end{array}$ & F & Sig. \\
\hline 1 Regression & 323.000 & 2 & 161.500 & 205.308 & $000^{\mathrm{a}}$ \\
Residual & 25.172 & 32 & 787 & & \\
Total & 348.171 & 34 & & & \\
\hline
\end{tabular}

a. Predictors: (Constant), X2, X1

b. Dependent Variable: Y

Sumber : Data Diolah (2014) 
Berdasarkan Tabel 3 menunjukkan bahwa hasil uji F sebesar205,308 dengan tingkat signifikan sebesar 0.000 sedangkan nilai F tabel sebesar 3,276. Jika dibandingkan nilai Fhitung $(205,308)$ > Ftabel $(3,276)$ pada alpha 5\% maka disimpulkan bahwa secara serempak variabel lingkungan kerja dan disiplin kerja berpengaruh positif dan signifikan terhadap kinerja pegawai.

\section{Hasil Uji Parsial (Uji t)}

Uji parsial (uji t) dilakukan untuk menguji secara parsial (individu) apakah insentif dan disiplin kerja berpengaruhterhadap motivasi kerja, dapat dilihat pada Tabel 4 berikut :

\section{Tabel 4}

\section{Hasil Uji Parsial (Uji t)}

Coefficients $^{\mathbf{a}}$

\begin{tabular}{|c|c|c|c|c|c|}
\hline \multirow[t]{2}{*}{ Model } & \multicolumn{2}{|c|}{$\begin{array}{l}\text { Unstandardize } \\
\text { d Coefficients }\end{array}$} & $\begin{array}{l}\text { Standardize } \\
\text { d } \\
\text { Coefficients }\end{array}$ & & \\
\hline & B & $\begin{array}{l}\text { Std. } \\
\text { Error }\end{array}$ & Beta & $t$ & Sig. \\
\hline 1 (Constant) & -1.055 & 1.396 & & .756 & 455 \\
\hline $\mathrm{X} 1$ & 106 & 157 & 085 & 672 & .507 \\
\hline $\mathrm{X} 2$ & 1.169 & 168 & 884 & 6.970 & .000 \\
\hline
\end{tabular}

a a. Dependent Variable: Y

\section{Sumber : Data Diolah (2014)}

Berdasarkan Tabel 4 terlihat

bahwa nilai untuk variabel

lingkungan kerja sebesar 0,672 dan disiplin kerja sebesar 6,970 dengan nilai signifikan untuk masing-masing variabel independen $(0,507) ;(0,000)$. Sedangkan untuk nilai tabel pada tabel statistik distribusi t dengan level of test $\alpha=5 \%$ dan $\mathrm{df}_{1}=35$ sebesar 1,681. Berdasarkan kriteria bahwa jika nilai thitung $>$ tabel yakni $(0,672<1,689) ;(6,970>1,689)$ sehingga dapat disimpulkan bahwa secara parsial variabel lingkungan kerja tidak pengaruh positif dan signifikan terhadap kinerja pegawai dan disiplin kerja berpengaruh positif dan signifikan terhadap kinerja pegawai. 


\section{Pembahasan}

Dari hasil pengujian secara serempak (uji F) bahwa nilai Fhitung $(79,349)>$ Ftabel $(3,276)$ pada alpha 5\% maka disimpulkan bahwa secara serempak variabel lingkungan kerja dan disiplin kerja berpengaruh positif dan signifikan terhadap kinerja pegawai. Berpengaruh positif dan signifikannya seluruh variabel independen terhadap variabel dependen memberikan makna bahwa seluruh variabel independen dan dependen memiliki keterkaitan yang erat.

Dari hasil penelitian dilihat bahwa variabel independen yaitu lingkungan kerja memiliki nilai thitung $<$ tabel atau $0,672<1,689$ dengan nilai probabilitas sebesar 0,507 >0,05, maka hipotesis Ha diterima yang berarti lingkungan kerja tidak berpengaruh positif dan signifikan terhadap kinerja pegawai. Hal ini dapat dijelaskan insentif sebagai sarana motivasi yang mendorong para pegawai untuk bekerja dengan kemampuan yang optimal, yang dimaksudkan sebagai pendapatan ekstra di luar gaji atau upah yang telah ditentukan. Pe mberian insentif dimaksudkan agar dapat memenuhi kebutuhan para pegawai dan keluarga mereka. Istilah sistem insentif pada umumnya digunakan untuk menggambarkan rencana-rencana pembayaran upah yang dikaitkan secara langsung atau tidak langsung dengan berbagai standar kinerja pegawai atau profitabilitas organisasi.

Sedangkan variabel independen yaitu disiplin kerja memiliki nilai thitung $>_{\text {ttabel }}$ atau 6,970 > 1,689 dengan nilai probabilitas sebesar $0,000<0,05$, maka Ha ditolak dan merupakan variabel independen disiplin kerja memiliki pengaruh paling dominan terhadap variabel kinerja pegawai. Hal ini dikarenakan variabel disiplin kerja merupakan suatu sikap menghormati, menghargai patuh dan taat terhadap peraturan-peraturan yang berlaku, baik yang tertulis maupun tidak, serta sanggup menjalankannya, serta tidak mengelak untuk menerima sanksisanksi apabila ia melanggar tugas dan wewenag yang diberikan kepadanya.

\section{KESIMPULAN DAN SARAN}

\section{Kesimpulan}

Berdasarkan uraian hasil penelitian dan pembahasan, dapat disimpulkan sebagai berikut :

1. Secara parsial bahwa variabel lingkungan kerja tidak berpengaruh positif dan signifikan terhadap kinerja pegawai.

2. Secara parsial bahwa variabel disiplin kerja berpengaruh positif dan signifikan terhadap kinerja pegawai.

3. Secara serempak bahwa variabel lingkungan kerja dan disiplin kerja berpengaruh positif dan signifikan terhadap kinerja pegawai. 


\section{Saran}

Berdasarkan hasil analisis dan kesimpulan penelitian, maka diajukan beberapa saran sebagai berikut :

- Kantor Dinas Perindustrian dan Perdagangan Kabupaten Labuhanbatu Utara, sebaiknya memperhatikan lingkungan kerja pegawai baik dengan memperhatikan fasilitasfasilitas dan kenyamanan ruangan kerja agar kinerja pegawai dalam menyelesaikan pekerjaan senantiasa terlaksana dengan baik.

- Kantor Dinas Perindustrian dan Perdagangan Kabupaten Labuhanbatu Utara, sebaiknya meningkatkan lingkungan kerja dan disiplin kerja keseluruhan alat perkakas dan bahan yang dihadapi, lingkungan sekitarnya di mana seseorang bekerja, metode kerjanya, serta pengaturan kerjanya baik sebagai perseorangan maupun sebagai kelompok.

- Kantor Dinas Perindustrian dan Perdagangan Kabupaten Labuhanbatu Utara, meningkatkan disiplin kerja dan lingkungan kerja fisik meliputi lingkungan kerja yang langsung berhubungan dengan karyawan seperti fasilitas dan sarana kerja, dan kategori kedua, lingkungan kerja umum yang mempengaruhi kondisi manusia seperti suhu, kelembaban, pencahayaan, kebisingan dan sirkulasi udara. Untuk lingkungan kerja non fisik meliputi hubungan kerja karyawan dengan rekan kerja, atasan maupun bawahan. 


\section{DAFTAR PUSTAKA}

Arikunto, S. 2006. Prosedur Penelitian Suatu Pendekatan Praktik. Rineka Cipta : Jakarta.

Fathoni, A. 2006. Manajemen Sumber Daya Manusia. Rineka Cipta : Jakarta.

Hasibuan, M. 2008. Manajemen Sumber Daya Manusia, Edisi Revisi. Bumi Aksara : Jakarta.

Hasibuan,Malayu S.P. 2001. Manajemen. Bumi Aksara. Jakarta Kuncoro, M. 2003. Metode Riset Untuk Bisnis \& Ekonomi. Erlangga : Jakarta. Mathis, Robert L \& John H Jackson. 2002.Manajemen Sumber Daya Manusia. Buku 2 Jakarta Salemba Empat Mulia, Nasution 2000. Manajemen Personalia, Jakarta : Djambatan Pusdiklat Pegawai Depdiknas. 2003 Prinsip Prinsip Manajemen Pelatihan, Sawangan Depok

Rivai, V. 2004. Manajemen Sumber Daya Manusia. Murai kencana : Jakarta.

Sastrohadiwiryo, B. Siswanto. 2002. Manajemen TenagaKerja Indonesia. Bumi Aksara : Jakarta.

Sedarmayanti. 2001. Sumber Daya Manusia Dan Produktivitas Kerja. Mandar Maju : Bandung.

Sekaran. 2006. Research Methods For Bussiness, Metodologi Penelitian II Bisnis, Edisi Keempat. Salemba Empat : Jakarta.

Sugiyono. 2008. Metode Penelitian Bisnis, Cetakan Kesebelas. Alfabet : Bandung. Hani Handoko. Manjemen Personalia dan Sumber Daya Manusia, Edisi Kedua Yogyakarta: BPEE Yogyakarta, 2003. 